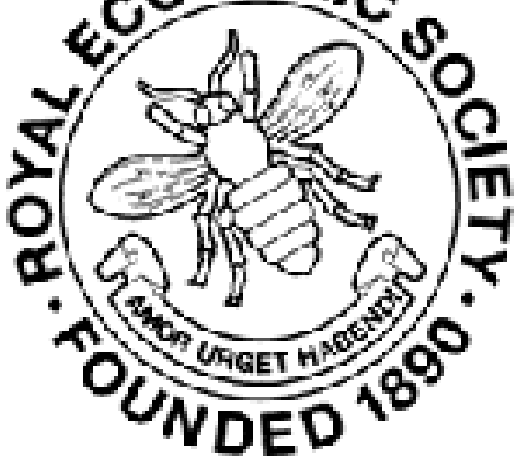

\title{
WILEY
}

The Social Importance of Banking

Author(s): F. Lavington

Source: The Economic Journal, Vol. 21, No. 81 (Mar., 1911), pp. 53-60

Published by: Wiley on behalf of the Royal Economic Society

Stable URL: http://www.jstor.org/stable/2222066

Accessed: 25-06-2016 03:17 UTC

Your use of the JSTOR archive indicates your acceptance of the Terms \& Conditions of Use, available at

http://about.jstor.org/terms

JSTOR is a not-for-profit service that helps scholars, researchers, and students discover, use, and build upon a wide range of content in a trusted digital archive. We use information technology and tools to increase productivity and facilitate new forms of scholarship. For more information about JSTOR, please contact support@jstor.org.

Royal Economic Society, Wiley are collaborating with JSTOR to digitize, preserve and extend access to The Economic Journal 


\section{THE SOCIAL IMPORTANCE OF BANKING}

THERE is something strangely contradictory to modern notions of organisation in the appearance of dense communities adjusting social resources to social wants with no central co-ordinating control.

Dispensation from this central control has been obtained by the operation of the principles of specialisation and exchange in reconciling the interests of the part and the whole. Where the individual can profit only by satisfying the wants of others, self-interest becomes in a large measure identified with social material welfare. The identification becomes complete, however, only in the following conditions :-

(1) Where competition is complete, so that on the one hand there is protection for the consumer, and on the other a guarantee for the survival of the most efficient type of organisation.

(2) Where the individual, in the adjustment of his resources, takes account of a very long period of time, so that the good and evil involved in his methods of business do not fall outside the period he considers. This fundamental defect of free enterprise -that individuals maximise their returns over the short period of one or two generations-and the social evils it involves are shown by the existence of the Factory and other restrictive Acts.

A special case of the defect forms the economic argument against Free Trade.

(3) Where, finally, the type of organisation in possession does not carry within itself defects which, owing to limitations of human knowledge and ability, competition has no tendency to eradicate.

Given these conditions individual and social material interests become identical, and the inspirations of free enterprise may safely be allowed to choose their direction and to run their course.

In our present "naturally" organised system, there is need in every branch of production for inquiry how far in fact the 
conditions diverge from those outlined; and in the event of any considerable divergence, a further need for restrictive or supplementary action to correct the disparity of interest between the part and the whole. In carrying the inquiry tentatively into banking it seems desirable first to notice the nature of the service performed, observing that in a banking system so highly specialised as in England, our great deposit banks limit themselves practically to two functions: namely, the transport of capital and the provision of a currency.

Of the great mass of wealth held by individuals in this country, the owners are content to retain only a part in their own use and to keep the remainder in the form merely of claims against others into whose possession it has passed. The influences governing individuals in this initial division are important, for they determine the magnitude of this second part of their wealth -that is, the amount of the general loan fund of capital within the country. It is the machinery for the conveyance of this mass of wealth from lenders to borrowers which first needs consideration.

Interposed between this first group of people having disposable wealth and a second group needing, and bidding for, its use, are various kinds of organisation offering competitively the service of transporting the mass from one to the other.

Foremost among these is the banking system; of secondary importance are solicitors, brokers, building societies, wholesale firms, pawnbrokers, and many others.

That the competition between these rival agencies is real, and that it intimately affects the future of the banks, is shown by the growing habit of investment through the broker, and the reflection of this in the diminution of average current account balances.

There is then a large body of persons owning wealth which they find it more convenient to lend than to use, and there are various channels by which this wealth may be passed into the hands of others. The difference between the rates paid by the borrowing group and the returns received by the lending group, constitutes the cost of transport, yields the middleman's profit, and measures the price which the community pays for the social service rendered.

Of this disposable wealth in the hands of the public the direction of a large part is quite determinable; it will flow to the banks for lodgment upon current account. It is thus set aside 
by its owners to yield, not interest, but the services of money. The depositors receive in exchange for its use, generally speaking, only the conveniences of the cheque system.

The remainder of the loanable wealth, flowing to borrowers through various channels, will come in part to the banks for lodgment upon deposit account.

The total amount of wealth, apart from capital and reserves, disposable by the banking system, consists of a large sum lent to them upon current account and a smaller upon deposit. In exchange for the former the banks provide a convenient currency; for the latter they pay a rate of interest. The whole of this is, broadly speaking, repayable upon demand, and the whole is distributed among the various classes of borrowers in accordance with two necessary conditions. First is the provision of a small gold reserve to meet demands for cash; the second, which practically creates the short loan market with all its dependent business, consists of the provision of a reserve of free capital to meet investment and other demands. The remaining resources, lent for longer periods, become embodied in more permanent forms throughout the country.

The nature of the services being such, inquiry is first needed to determine whether the consumer is adequately protected by free competition, or whether, as their abnormally high profits suggest, the banks have some monopoly power.

The rate of profit must properly be calculated on the true working capital, to find which there must be added to the paidup capital, first, at least a part of the great reserve funds used in the business; secondly, an addition for the valuable immaterial organisation-business connections and public confidence-which, having a cost of production, must also yield a return; thirdly, an allowance for the uncalled capital, in so far as this increases their credit and checks the flow of investment into banking.

Even, however, when profits are estimated upon this larger figure, they still appear to be higher than elsewhere. It is necessary to examine separately the costs of their two services, dealing first with that of transporting capital.

Inasmuch as the transporting agencies have, on the one hand, no control over the amount of disposable wealth within the country, or on the other, over the willingness of borrowers to pay for its use, it is clear that they can have no real control over the rate at which the predetermined volume of capital is just taken off their hands. They affect rates when, once for all, they decide upon the policy which determines the proportionate distribu- 
tion of their funds between the long and short loan markets, and they may vary rates temporarily by varying these proportions; but they cannot, in the long run, control the terms of a bargain in which they are merely intermediaries.

The net rate of interest which just carries off the volume of capital in the hands of the banks determines the price which they, in their turn, can offer to the public for the use of its disposable wealth. No doubt there is some reaction between the rate thus offered and the supply of capital coming forward, but as this is probably slight it is neglected.

The limit of the price which banks are able to offer to the public is that which is below their net loan rate by an amount which just yields them a normal profit on their true capital, and there can be no doubt that this marginal rate is given when the bank's customer demands it. But the number of those who bargain with their banker is not very great, and it seems that it is here, in the ignorance of the customer, in his desire to stand well with his banker, that the explanation of high bank dividends lies. Deposit account rates are not uniform; the maximum marginal rate goes only to those who demand it; lower rates go to the less importunate. The partial absence of the economic relation between banker and customer is even more important in current accounts, where the customer receives not a definite rate of interest but the convenience of the cheque system, and where accordingly the terms are more vague and the range of variation is greater. If one or two banks may be taken as in this respect roughly representative of all, then of the $£ 900,000,000$ odd of aggregate lodgments some $£ 600,000,000$ are upon current account. In exchange for the use of this latter sum and for the commissions charged the banks supply the service of the cheque currency. The social cost of this is therefore the total of the commissions, which is not known, plus the use of some $\$ 600,000,000$ of capital repayable upon demand, the value of which may be roughly estimated at deposit rates, say 2 per cent., as $£ 12,000,000$ per annum. The difference between this amount and the actual cost of providing the cheque currency must be very great-and quite sufficient to explain the excessive profits of banking.

It appears then that the cost to society of the two great services supplied by the banks-particularly that of the provision of currency-is unduly high; but the excessive profit seems to be due, not to the existence of monopoly power, but to the imperfect bargaining between banker and customer. Moreover, there is 
no great social evil involved, for the surplus profit is in effect only a transfer from an inert class in possession of disposable wealth to a body of shareholders probably in much the same condition of well-being. A word next in regard to the method in which resources are adjusted to yield these services as distinguished from the price at which they are sold.

The change towards democratic institutions has extended from States to banks. Selection of the governing body by the uncertain action of heredity has given way to conscious choice by election. The change has eliminated the immense waste of business structures under semi-hereditary management and brought a great stability to our banking institutions. This stability has resulted in the adoption of a very far-seeing policy, and of methods of business far removed from those containing such social evils as are apparent in other directions; where, for instance, Adulteration and Truck Acts mark evils which flow directly from the short period of time taken into account by the individual entrepreneur.

Given, however, the presence of free competition and an enlightened and far-seeing policy, it is still possible that the type of organisation in possession, although on the whole the most efficient which human ingenuity can at present construct, still contains defects sufficiently serious to justify independent supplementary or restrictive action. Consider this for a moment. The social interest in the transport of capital is simply stated. It is maximised by the conveyance of capital into the hands of those most capable of using it. In so far as the most competent to use capital are also those who are most able to pay the highest net rate for its use, the self-interest of the banks, subject to their reserve policy, is identical with that of the community. But their present structure, although superior to that which it has replaced, is imperfectly adapted to effect this.

The great joint stock banks of to-day seem to have grown in size partly from causes and facilities in common with production generally, partly in adaptation to the demands of larger scale business. Their superior size and management give the public greater security and distribute capital much more evenly over the country. But it seems inevitable that the local knowledge possessed by their changing branch managers should be inferior to that of the small private banker, and that this imperfect knowledge of persons, combined with the practical necessity of sanctioning loans from the head office, should result in a highly objective loan policy. The nature of the security offered must 
be given an undue predominance over the character of the person borrowing; small loans, inasmuch as they involve as much trouble as the larger, become relatively less profitable and tend to be discouraged. This defect of rigidity tends against the ideal distribution of capital, and results in the partial exclusion from its use of a class of persons whose offer of security is less attractive than that of others, but whose capabilities give them a better social title to its use.

The modern development of banking institutions seems, however, to be better adapted to the second function of bankingthe provision of currency.

The social interest requires that this currency should adapt itself readily to changes in the demand for its use; that is, that is should have a high degree of elasticity. It requires further, in order that equitable contracts may be made by parties who are not financial experts, that the value of the unit of currency should vary as little as possible from changes due to its own supply.

But there are, as is well known, wide oscillations of general prices which occur at fairly regular intervals, and which are rendered possible only by the great elasticity in the volume of our exchange media. It is recognised that these oscillations add greatly to the risks of business undertaking, thus increasing costs of production, and by their disturbing effects (upon employment in particular) form a social evil of the first importance.

Their regulation is in part a question of the regulation of currency, and as such may be briefly considered here.

From the total volume of our exchange media may be separated book-debts, bills and similar instruments, control over the creation of which is at present impossible, and attention may be given to the most elastic-and therefore for these purposes the most important-part of the remainder, the cheque currency.

The volume of this may be considered as a multiple of the gold reserve; the figure by which the amount of the gold is multiplied being fixed by the banks as high as possible, and determined quite empirically by long experience of what is safe. The volume of the cheque currency may then be expanded by an increase, or contracted by a diminution, of this figure at the will of the banking system. There is a further elasticity-beyond their control-as is shown by wide movements of the Clearing House returns independently of the gold reserve.

The method of operating against general price fluctuations is 
through the deliberate regulation by the banks of this part of the currency which is under their collective control.

Suppose at any moment the gold reserve to be say $£ 30,000,000$, and to be multiplied by the banking system by, say twenty, to give a total available cheque currency of $£ 600,000,000$. Then if the banks choose to change this figure to twenty-one, they are able to increase their loans, and as a result their deposits also, by $£ 30,000,000$. The amount of capital within the country remains unaltered, but the currency in which it is expressed has been diluted and the general price-level tends to rise. This process reversed would operate against rising prices and temper the severity of their fluctuations. The mere knowledge that such an operation was likely would tend to prevent that rise of prices which occurs solely because prices are rising.

At the present time the currency policy of the joint stock banks appears to be almost entirely a defensive one. Abnormal currency conditions become known to them only by financial pressures which disturb the determined proportions between gold liabilities and gold reserve-they respond with efforts to recover the normal adjustments. They react as experience has shown necessary. Their action follows and does not control shifting financial conditions.

The bank rate, followed irregularly by the market rate, is adjusted to meet pressures on the gold reserve both from abroad and at home; it cannot therefore be adapted primarily to control the home currency until the reserve is so strong that such possible foreign demands as are separable from this purpose may be neglected. But it would seem that a larger reserve, however desirable in the presence of certain kinds of gold drain, would yet, as things are now, have the great disadvantage of rendering our banking system less sensitive to internal changes in financial conditions, and accordingly less quick to take action by restricted lending against inflated general prices. The bank rate, already used to make provision against seasonal changes, appears to reflect rather than to govern the wider movements in the demand for currency.

In order that changes in price levels might be tempered by the substitution of an aggressive for a defensive currency policy two conditions would appear to be necessary.

First, the possibility of common action by the banks to control discount rates and the supply of currency.

Secondly, owing to the complexity of financial conditions, the growth of banking experience and tradition by which alone such 
a policy could safely be carried into effect. Given these, there seems no reason why there should not develop a common control over the cheque currency which, on the one hand, should avoid those financial conditions which directly promote speculative activity, and on the other operate directly to reduce the inflations which such activity fosters. To these ends the permanence of our banking institutions and their increasing concentration seem peculiarly adapted.

To conclude, in an industrial system such as this, where the domination of a central authority is replaced by an initiative springing from a multitude of points within the group, the question of supreme interest is to measure the divergence between the lines of direction of individual action and those of material social welfare. The supreme need is to attain a perfect parallelism without weakening the impulses of self-interest.

This paper has briefly attempted the examination of a particular branch of production-that of banking. As a result, it is suggested that in this case abnormally high profits do not necessarily indicate the existence of monopoly power, but that, in fact, competition adequately protects the consumer from all but his own ignorance or inclination; that the high social cost of banking services is not a considerable evil.

The banks seem equally free from the second and most important source of divergence which proceeds from that adjustment of means to ends which maximises profits over a short period. They pursue a far-seeing policy, which accordingly involves in its methods of business no great social evils.

But the type of organisation evolved-although perhaps the best to which human knowledge and experience can as yet attain-contains a defect of rigidity which partly unfits it to perform the service of transporting capital to certain classes very capable of using it well.

The organisation seemed better fitted for the provision of a very convenient currency, and it is suggested that this service may, by the growth of experience and common action, be extended to promote an active currency policy which may appreciably temper fluctuations in general price levels and diminish the evils they involve.

If these considerations are sound it seems to follow that there is an exceptionally close identification between the self-interest of banks and the general material welfare of society, and that there is every reason to welcome recent changes in the system and to expect greater services in the future. 